Check for updates

Cite this: RSC Adv., 2019, 9, 257

Received 28th August 2018

Accepted 7th December 2018

DOI: $10.1039 / c 8 r a 07177 b$

rsc.li/rsc-advances

\section{Probing of complex carbon nanofiber paper as gas- diffusion electrode for high temperature polymer electrolyte membrane fuel cell $\uparrow$}

\author{
Igor I. Ponomarev, (D) *a Kirill M. Skupov, (D) a Alexander V. Naumkin, (D) a \\ Victoria G. Basu, ID bc Olga M. Zhigalina, ${ }^{\text {bd }}$ Dmitry Y. Razorenov, (iD a \\ Ivan I. Ponomarev ${ }^{a}$ and Yulia A. Volkova ${ }^{a}$
}

\begin{abstract}
The development of fuel cells is an important part of alternative energy studies. High-temperature polymer electrolyte membrane fuel cell (HT-PEMFC) is a very promising and commercialized type of fuel cell since it allows the use of hydrogen contaminated with CO. However, current advances in HT-PEMFC are based on searching for more sustainable materials for the membrane electrode assembly. The key issue is to find new, more stable carbonaceous Pt-electrocatalyst supports instead of the traditional carbon black powder. In the present study, we primarily demonstrate a new electrode design concept. Complex carbon nanofiber paper (CNFP) electrodes, obtained by polyacrylonitrile (PAN) electrospinning with further pyrolysis at $900-1200{ }^{\circ} \mathrm{C}$, are suitable for platinum deposition and were probed as the gas-diffusion electrode for HT-PEMFC. Complex composite electrodes were obtained by introducing zirconium and nickel salts into the electrospinning PAN solution. After pyrolysis, $\mathrm{ZrO}_{x}$ and $\mathrm{Ni}(0)$ nanoparticles were distributed in the CNFP throughout the whole nanofiber volume, as it is seen in the high-resolution transmission electron microscopy images. The samples were thoroughly studied by X-ray photoelectron, Raman and impedance spectroscopy, cyclic voltammetry, and elemental analysis. The MEAs designed on platinized composite CNFPs demonstrate higher performance at $180^{\circ} \mathrm{C}$ compared to non-composite ones and are comparable with commercial Celtec ${ }^{\circledR} \mathrm{P} 1000$.
\end{abstract}

\section{Introduction}

The polymer electrolyte membrane fuel cell (PEMFC) is a clean energy-converting device that has attracted significant attention in the last two decades due to its high efficiency, high energy density, and low or zero emissions. ${ }^{1-7}$ PEMFC has several important application areas including transportation, stationary as well as portable and micro-power devices. However, major technological gaps that hinder its commercialization have been revealed, namely high cost and low durability. Increasing the durability of the electrocatalyst carbon support by replacement of the carbon black powder with more sustainable materials is the major challenge. Current efforts in this field are focused on searching for cost effective, active, and stable fuel cell catalysts

\footnotetext{
${ }^{a}$ Nesmeyanov Institute of Organoelement Compounds, Russian Academy of Sciences, Vavilova St., 28, Moscow, 119991, Russia. E-mail: gagapon@ineos.ac.ru

${ }^{b}$ Shubnikov Institute of Crystallography of Federal Scientific Research Centre "Crystallography and Photonics" of Russian Academy of Sciences, Leninsky Av., 59, Moscow, 119333, Russia

"National Research Center "Kurchatov Institute", Akademika Kurchatova Sq., 1, Moscow, 123182, Russia

${ }^{d}$ Bauman Moscow State Technical University, 2nd Baumanskaya St., 5, Moscow, 105005, Russia

$\uparrow$ Electronic supplementary information (ESI) available: CV, EIS, and BET specific surface area data. See DOI: 10.1039/c8ra07177b
}

for both the anodic hydrogen oxidation reaction and the cathodic oxygen reduction reaction (ORR), which takes place within the active catalyst layers.

High-temperature polymer electrolyte membrane fuel cell (HT-PEMFC) based on a polybenzimidazole $(\mathrm{PBI}) / \mathrm{H}_{3} \mathrm{PO}_{4}$ membrane, usually operated at $150-200{ }^{\circ} \mathrm{C}$, is considered to be the next generation of fuel cell technology due to the reduced cost and reliability in terms of improved reaction kinetics, catalyst tolerance, heat rejection and water management. ${ }^{2-7}$ One of the main challenges hindering their success is material degradation, particularly that of the highly porous carbon Pt support with further detachment, loss and aggregation of the metal electrocatalyst particles. ${ }^{8}$ The fabrication of a new electrode for hydrogen-air HT-PEMFC with PBI type membrane is a complex fundamental, scientific and technical challenge. ${ }^{8-11}$ Increase in the fuel cell performance directly depends on the quality of the gas-diffusion electrodes.

Approaches towards the gas-diffusion electrode (GDE) design are quite versatile (Fig. 1), but generally include the application of a catalytic ink (aqueous/alcohol dispersions of perfluoropolymers and electrocatalysts $\mathrm{Pt} / \mathrm{C}$ ) on carbon paper or tissue with a perfluorinated hydrophobic microporous layer. ${ }^{\mathbf{1 , 4}}$

For the first time, we proved the possibility of fabricating platinum GDEs based on a carbon nanofiber non-woven self- 


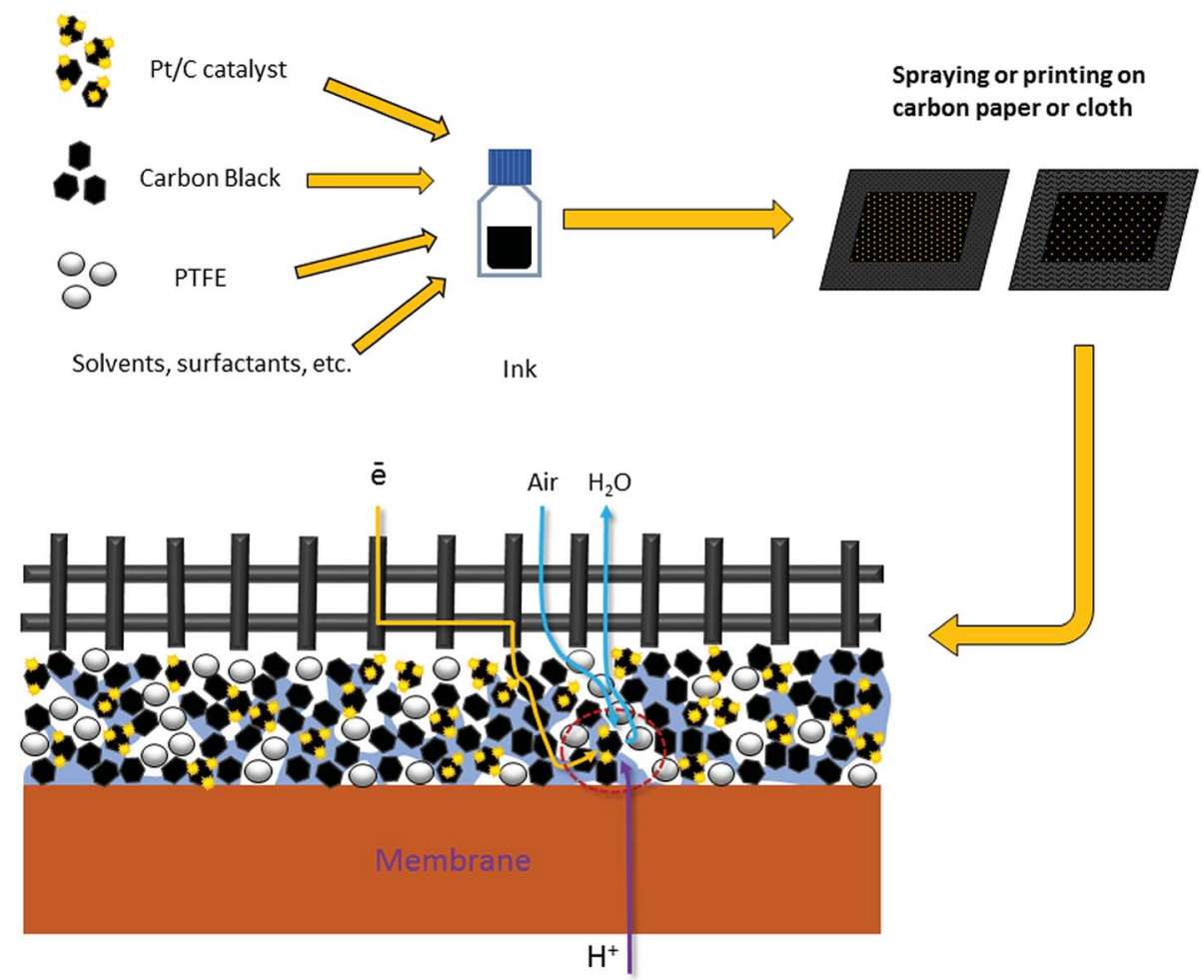

Fig. 1 Traditional electrode fabrication with gas-diffusion limits.

supporting material for the membrane electrode assembly (MEA) of a hydrogen-air HT-PEMFC ${ }^{12-14}$ where the PBI-O-Pht/ $\mathrm{H}_{3} \mathrm{PO}_{4}$ membrane, namely a membrane of PBI type, developed by our group in the Institute of Organoelement Compounds (INEOS RAS) ${ }^{15-17}$ was used. For this, the electrospinning method from a polymer solution was applied; the method has been used to prepare carbon nanofibers (CNF) in many applications. ${ }^{18-23}$ By the electrospinning method, polyacrylonitrile was electrospun on a flat surface providing polymer nanofiber $(50-300 \mathrm{~nm}$ in diameter) mats. For the next step, during oxidation (stabilization) in air at $250-350{ }^{\circ} \mathrm{C}$, partially oxidized nanofiber polymer mats with nitrogen containing heterocycles in their structure were obtained as described in literature. ${ }^{24}$ Finally the carbon nanofiber paper (CNFP) was formed when the stabilized polymer mats were pyrolyzed (carbonized) at $900-1200^{\circ} \mathrm{C}$ under vacuum to form CNFP sheets. The aforementioned CNFPs are suitable for nanocrystalline platinum $(1.5-5 \mathrm{~nm})$ deposition by dipping directly into an $\mathrm{H}_{2}\left[\mathrm{PtCl}_{6}\right]$ aqueous solution as confirmed by scanning and transmission electron microscopy. ${ }^{25}$ As a result, a new type of FC electrodes is formed (Fig. 2), which avoids some of the drawbacks of the traditional "ink-type" electrode preparation method.

Earlier we have demonstrated that this type of noncomposite GDEs could be used as anodes ${ }^{14}$ and cathodes ${ }^{12}$ for HT-PEMFC, but in spite of the GDE advantages, the electrodes showed a performance that was lower compared to that of the commercial Celtec $\circledast$ P1000.

In this study, we probe a complex composite carbonized electrospun material on the basis of platinized PAN CNF with $\mathrm{Zr}$ and $\mathrm{Ni}$ distributed throughout the nanofibers as HT-PEMFC electrode.

\section{Experimental}

\section{Electrospinning}

$100 \mathrm{~g}$ DMF solution of polyacrylonitrile (PAN) polymer (7\% wt) and $0.57 \mathrm{~g}$ of carbon black Vulcan® XC72 (Vulcan) were sonicated in an ultrasonic bath at $50-60{ }^{\circ} \mathrm{C}$. A separate solution was prepared using $0.89 \mathrm{~g}$ nickel(II) acetate tetrahydrate and $0.058 \mathrm{~g}$ zirconium(rv) chloride in $2 \mathrm{~mL}$ of DMF (amounts of $\mathrm{Ni}(\mathrm{OAc})_{2^{-}}$ $\cdot 4 \mathrm{H}_{2} \mathrm{O}$ and $\mathrm{ZrCl}_{4}$ were varied to obtain PAN/Vulcan/Zr/Ni nanofiber mats with different $\mathrm{Ni}$ and $\mathrm{Zr}$ content). The two solutions were mixed under vigorous stirring and sonicated in an ultrasonic bath at $50-60{ }^{\circ} \mathrm{C}$. Electrospinning was carried out on an Elmarco Nanospider ${ }^{\mathrm{TM}}$ NS LAB setup (Czech Republic). The electrospinning was performed at $28{ }^{\circ} \mathrm{C}$ with a relative humidity of $12-18 \%$, a distance of $190 \mathrm{~mm}$ between the electrodes, a linear carrier velocity of $3 \mathrm{~mm} \mathrm{~s}^{-1}$ and carriage velocity of $300 \mathrm{~mm} \mathrm{~s}^{-1}$. The electrospinning was processed at $75 \mathrm{kV}$ and $0.06 \mu$ A. Finally, a PAN/Vulcan/Zr/Ni nanofiber polymer composite precursor mat was obtained.

\section{Electrode preparation}

Electrocatalyst support preparation. Carbonized electrocatalyst supports, PAN/Vulcan/Zr/Ni-350-1000 (samples 1-3) with different $\mathrm{Ni}$ and $\mathrm{Zr}$ contents, were prepared by thermal treatment of the composite polymer precursor PAN/Vulcan/Zr/ $\mathrm{Ni}$. In the first thermal treatment step, an electrospun composite polymer precursor mat was oxidized (or stabilized) at $350{ }^{\circ} \mathrm{C}$ in air. In the second step, the material was carbonized by pyrolyzing at $1000{ }^{\circ} \mathrm{C}$ under vacuum $\left(10^{-5}\right.$ torr $)$, resulting in 

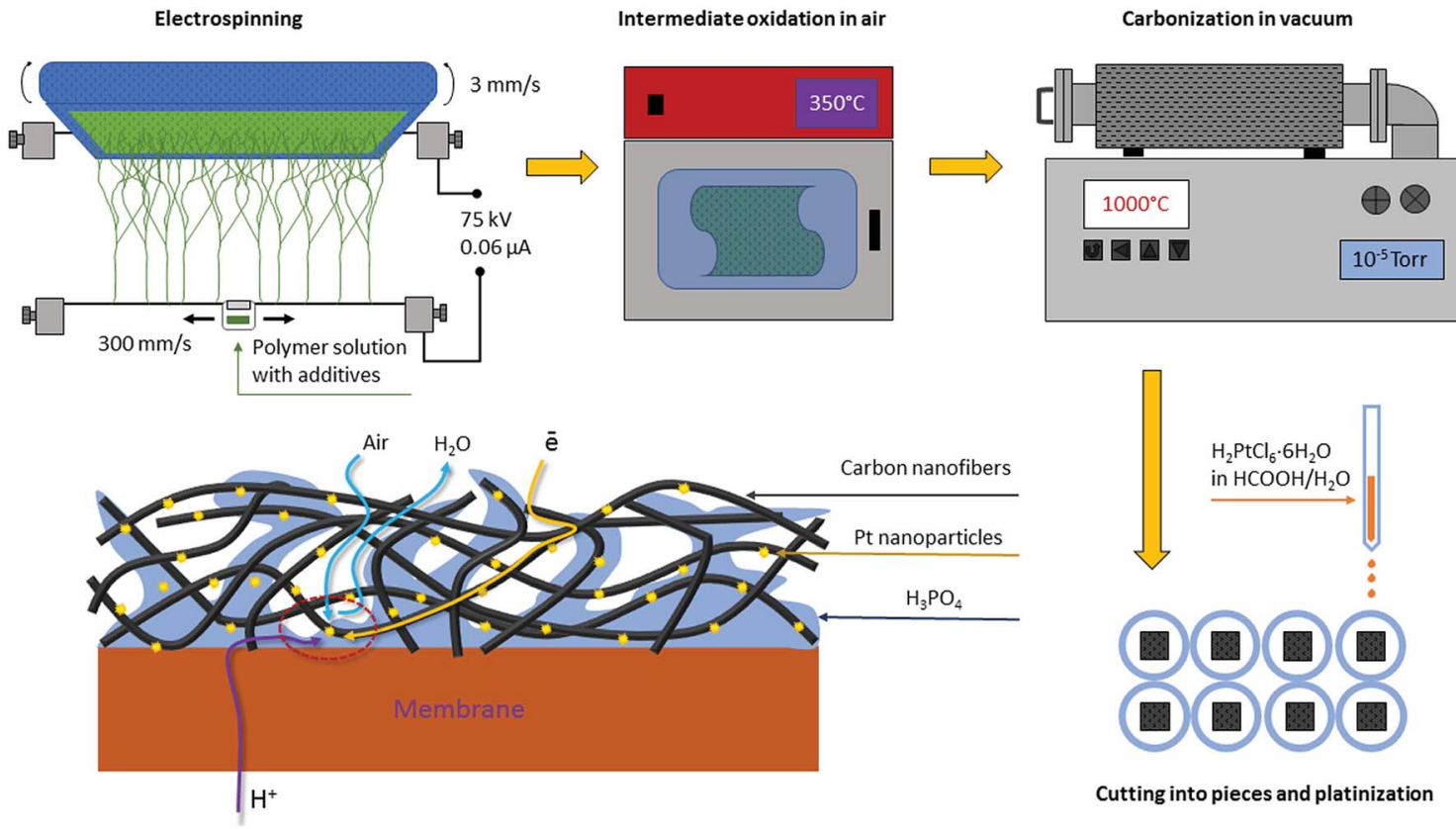

Fig. 2 CNFP electrode preparation scheme. Integrity, high air permeability, low electrical resistance and residual nitrogen content (1.5-8.0\%) are indispensable for organizing triple-phase boundary.

a carbonized material, CNFP. The elemental contents and electrical conductivities of the carbonized electrocatalyst supports (samples 1-3) are shown in Table 1.

Platinization. Electrocatalyst Pt nanoparticles were deposited on samples 1-3 by Pt reduction in a formic acid aqueous solution. $129 \mathrm{mg}$ of $\mathrm{H}_{2}\left[\mathrm{PtCl}_{6}\right] \cdot 6 \mathrm{H}_{2} \mathrm{O}$ (final Pt nanoparticle content 1.2 $\mathrm{mg}_{\mathrm{Pt}} \mathrm{cm}^{-2}$ ) were dissolved with $3 \mathrm{~g}$ of $\mathrm{HCOOH}$ in $60 \mathrm{~mL}$ of deionized water. The solution was then divided into 6 equal parts and each part ( $\sim 10 \mathrm{~g}$ ) was applied to the electrocatalyst support and left overnight. Each sample in the electrocatalyst support represented a square mat of composite pyropolymer with an area of $6.76 \mathrm{~cm}^{2}$. Pt deposition was visually observed by the total disappearance of the yellow color of $\mathrm{H}_{2}\left[\mathrm{PtCl}_{6}\right]$. The samples were dried under vacuum at $100{ }^{\circ} \mathrm{C}$, resulting in samples that were suitable for use as HT-PEMFC gas-diffusion electrodes. Platinized samples, Pt/PAN/Vulcan/Zr/Ni-350-1000, are mentioned in the text as samples 1a-3a correspondingly. After platinization, the Pt content for 1a-3a were 19.1, 28.8 and $14.9 \mathrm{wt} \%$ of the total sample mass respectively.

Scanning electron microscopy (SEM) top view images before and after platinization are shown in Fig. 3.

As seen in Fig. 3, the nanofiber surface is covered by a uniform platinum layer. More detailed images of the platinated nanofiber structures for similar nanofibers were reported in our previous study. ${ }^{25}$

Table 1 Elemental contents and electrical conductivities of the electrocatalyst supports (samples 1-3)

\begin{tabular}{lllllll}
\hline Sample & $\mathrm{C}, \%$ & $\mathrm{~N}, \%$ & $\mathrm{H}, \%$ & $\mathrm{Zr}, \%$ & $\mathrm{Ni}, \%$ & $\sigma, \mathrm{S} \mathrm{cm}^{-1}$ \\
\hline 1 & 85.91 & 1.83 & 0.25 & 0.98 & 5.98 & 25.0 \\
2 & 88.47 & 1.61 & - & 2.3 & 5.6 & 22.5 \\
3 & 86.88 & 2.34 & 0.71 & 1.1 & 4.5 & 10.1
\end{tabular}

\section{Fuel cell testing}

Just before testing the fuel cell, samples $1 \mathrm{a}-3 \mathrm{a}$ were hydrophobized by Teflon ${ }^{\circledR}$ AF by dipping the sample in octafluorotoluene (10 $\mathrm{mg}$ of Teflon ${ }^{\circledR} \mathrm{AF} / 10 \mathrm{~mL}$ of octafluorotoluene) for $1 \mathrm{~min}$ and treating at $280{ }^{\circ} \mathrm{C}$ under vacuum for $2 \mathrm{~h}$.

For cathode testing, cells with active surface areas of $5 \mathrm{~cm}^{2}$ were assembled and samples $1 \mathrm{a}-3 \mathrm{a}$ were used as the cathodes (BET specific surface area for 1 is $60.5 \mathrm{~m}^{2} \mathrm{~g}^{-1}$, Fig. S2 in ESI†). Standard commercial anode Celtec ${ }^{\circledR}$ P1000 (BASF) ${ }^{26}$ based on carbon black Vulcan ${ }^{\circledR}$ XC-72 (BET specific surface area of carbon black is $213 \mathrm{~m}^{2} \mathrm{~g}^{-1}$ according to ref. 27) with a Pt load of $1 \mathrm{mg}$ $\mathrm{cm}^{-2}\left(40 \% \mathrm{Pt} / \mathrm{C}\right.$ ratio $\left.{ }^{15}\right)$ was used. For the commercial sample, a standard commercial cathode Celtec ${ }^{\circledR}$ P1000 (BASF) was used (containing Vulcan ${ }^{\circledR}$ XC-72 supported Pt-alloy with $0.75 \mathrm{mg} \mathrm{cm}{ }^{2}$ of Pt). A polymer electrolyte proton conducting membrane, PBIOPht, ${ }^{15}$ which was developed earlier in our group, was used for MEA assembling. The membrane was modified by zirconium acetylacetonate and doped with $o$-phosphoric acid by $350-400 \%$, which corresponds to $25 o$-phosphoric acid molecules per polymer unit. Since these anodes and membranes were found to provide quite reproducible results, they were used to achieve a reliable comparison for different cathodes. MEAs were assembled within standard fuel cell hardware units (Arbin Instruments) such as graphite bipolar plates with an electrical current collector and gas supplies. Fuel cell tests were performed at $180{ }^{\circ} \mathrm{C}$. Hydrogen was supplied from a hydrogen generator GVCh-6 (Khimelektronika) at $100 \mathrm{~mL} \mathrm{~min}^{-1}$. Atmospheric air was supplied at $300 \mathrm{~mL} \mathrm{~min}{ }^{-1}$ (stoichiometry 6 at $0.6 \mathrm{~A} \mathrm{~cm}^{-2}$ ) in order to prevent oxygen mass-transfer limitations ${ }^{15}$ without additional humidification at atmospheric pressure. Polarization curves were obtained at a current density range of $0-0.8 \mathrm{~A} \mathrm{~cm}^{-2}$ at $180{ }^{\circ} \mathrm{C}$ with a current step of $0.02 \mathrm{~A} \mathrm{~cm}^{-2}$. The voltage 


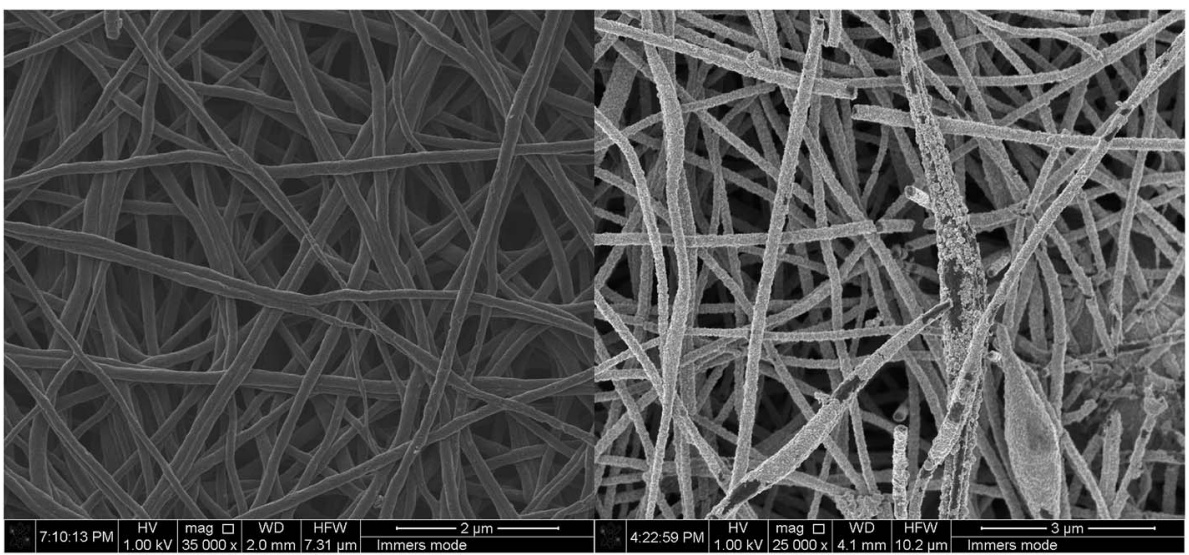

Fig. 3 SEM top view images of the nanofiber mat before (left) and after (right) platinization.

measurements were performed after $5 \mathrm{~s}$ of current setting. The time test was performed at a current density of $0.6 \mathrm{~A} \mathrm{~cm}^{-2}$ at $180{ }^{\circ} \mathrm{C}$ for $170 \mathrm{~h}$. Electrochemical impedance measurements of the fuel cells were conducted in a galvanostatic mode through a range of frequencies (from $100 \mathrm{kHz}$ to $0.1 \mathrm{~Hz}$ ) for different current density values with a magnitude of current perturbation of $2 \mathrm{~mA} \mathrm{~cm}^{-2}$.

\section{Material characterization}

The specific surface area data for the carbon materials were obtained by performing multi-point BET analysis using NOVAe ${ }^{\circledR}$ Series Surface Area Analyzer (Quantachrome Instruments). Electrical conductivity measurements of the nanofiber mats were performed with a 4-point digital setup LCR E7-8 (Russia). Raman spectra were obtained using Horiba-Jobin Yvon LabRAM Raman laser spectrometer with $\times 50$ and $\times 100$ microscope. A He-Ne laser of 0.1-0.01 $\mathrm{mW}$ was used as an excitation source.

\section{XPS studies}

The X-ray photoelectron spectra were recorded using an Omicron spectrometer (UK) with $\mathrm{Mg} \mathrm{K} \alpha$ radiation in the fixed analyzer transmission mode. The analyzer pass energy was set at $100 \mathrm{eV}$ for registration of the survey and $40 \mathrm{eV}$ for measuring high-resolution spectra. The spectra were measured with a step size of $0.1 \mathrm{eV}$ at room temperature. The energy scale of the spectrometer was calibrated according to the standard procedure taking into account the following binding energies: 932.7, 368.3 and $84.0 \mathrm{eV}$ for $\mathrm{Cu} 2 \mathrm{p}_{3 / 2}, \mathrm{Ag} 3 \mathrm{~d}_{5 / 2}$, and $\mathrm{Au} 4 \mathrm{f}_{7 / 2}$, respectively. The residual pressure inside the analysis chamber was lower than $1.0 \times 10^{-9}$ mbar. The photoelectron spectra were approximated by a Gauss function or the sum of Gauss functions, and the background caused by secondary electrons and photoelectrons that lost energy was approximated by Shirleytype background line. Quantification was performed using atomic sensitivity factors included in the software of the spectrometer. The samples were fixed to the sample holder by double-sided adhesive tape. Sample charging was corrected by referencing to the $\mathrm{sp}^{2}$ state in the $\mathrm{C} 1 \mathrm{~s}$ spectrum $(284.44 \mathrm{eV}) .^{28}$

\section{Electron microscopy}

Nanofiber images were obtained by scanning electron microscopy (SEM) on a FEI Quanta 250 FEG and FEI Helios 600. Transmission electron microscopy (TEM), scanning transmission electron microscopy (STEM) images and EDX elemental mapping were obtained on a FEI Tecnai Osiris equipped with Super-X EDX detection system (FEI) based on Silicon Drift Detector (SDD) technology and high angle annular dark field (HAADF) detector. The high sensitivity system allows for the detection of all elements down to and including boron; high output count rates and maximum collection efficiency provide quick time-to-data even for low intensity EDX signals. For electron microscopy studies, nanofiber samples were dispersed in acetone using an ultrasonic bath for 5-30 min to obtain single nanofibers. The resulting suspensions were dropped onto $\mathrm{Cu}$ lacey carbon grids. To visualize structure details, low voltage immersion mode (FEI Helios 600) and environmental mode (FEI Quanta 250 FEG) were applied for obtaining SEM images.

See $\mathrm{ESI} \dagger$ for additional information on cyclic voltammetry (CV), electrochemical impedance spectroscopy (EIS), and BET specific surface area data.

\section{Results and discussion}

\section{Fuel cell performance}

For effective performance, a hydrogen-air HT-PEMFC MEA generally requires a balance between gas (hydrogen, air) permeability, proton conductivity and electron conductivity. In the traditional so-called "ink-type" electrode (Fig. 1), carbon black plays the role of the electron conductor where protons are conducted through pores distributed in the carbon black in a phosphoric acid media. To organize gas permeability, polytetrafluoroethylene (PTFE) is added to the "ink". Due to its high hydrophobicity, the gases move through the electrode along the border between the hydrophobic PTFE and the phosphoric acid media. In this case, the required triple boundary point for electrocatalysis appears. For our new CNFP electrode, the organization and optimization of balance between gas 
permeability, proton conductivity and electron conductivity on the triple boundary point is also a very important task. The CNFs definitely improve the percolating network for electron conductivity (Fig. 4 and 5). Our 3D investigations of single carbon nanofibers using the electron tomography method have visualized large pores in the fiber volume (which corresponds to around $20 \%$ of the CNF diameter). Cavities and pores are formed by loops of parallel graphene layer sets, which appear as a result of the fiber crystallization during the annealing process. ${ }^{25}$ For proton conductivity, the phosphoric acid is distributed in the pores (total specific pore surface is $60-300 \mathrm{~m}^{2}$ $\mathrm{g}^{-1}$ ) on the CNF. Protonation of residual nitrogen atoms (which still exist in CNF after polymer composite mat pyrolysis) also occurs, and it helps better proton conductivity. Our previously studied materials ${ }^{14}$ were obtained by electrospinning of the PAN/carbon black solution with further pyrolysis, and showed some limitations with proton transport according to the EIS Nyquist plot (see ESI, Fig. S3†). To overcome this difficulty, a composite electrode was produced, in which a solution of PAN with a low content of carbon black and of $\mathrm{Zr}$ and Ni salts were used for electrospinning followed by pyrolysis. As expected, after the two step thermal treatment (oxidation and pyrolysis), $\mathrm{Zr}$ appeared in the electrode in the form of $\mathrm{ZrO}_{x}$ distributed homogeneously throughout the nanofibers, which interacted with phosphoric acid leading to the formation of acid sites to

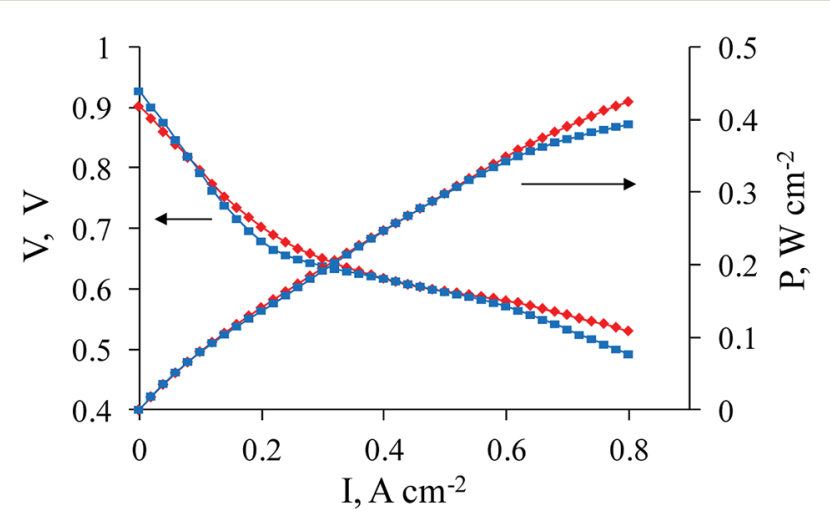

Fig. 4 Polarization and power density curves $\left(180^{\circ} \mathrm{C}\right)$ for commercial cathode Celtec $\circledast$ P1000 (BASF) (blue line, squares) and for sample $1 \mathrm{a}$ as a cathode (red line, rhombi).

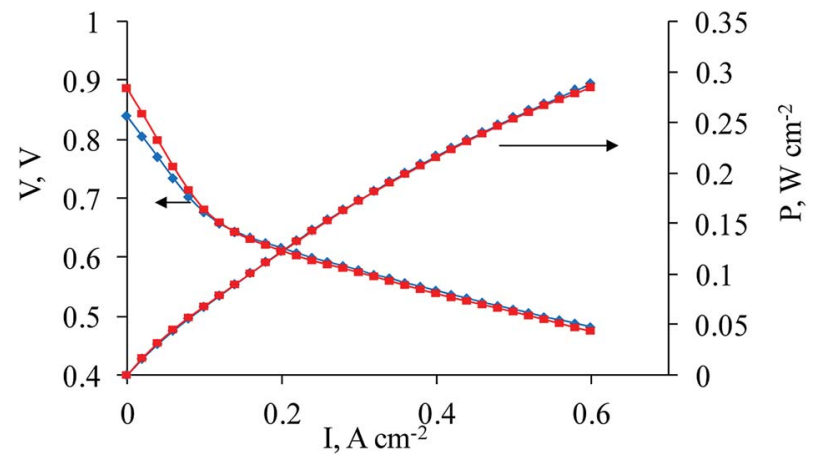

Fig. 5 Polarization and power density curves $\left(180^{\circ} \mathrm{C}\right)$ for sample $2 \mathrm{a}$ (blue line, rhombi) and sample $3 a$ (red line, squares) as cathodes. improve proton transport. After pyrolysis, $\mathrm{Ni}$ is expected to be present in the form of $\mathrm{Ni}(0)$, distributed throughout the nanofibers. It may play the role of small sized seeds to improve platinum deposition on the PAN/Vulcan/Zr/Ni-350-1000 support, and as a doping metal for platinum to promote ORR on the cathode. The "improved" shape of the EIS Nyquist plot was registered (see ESI, Fig. S4†), which can be related to the improved proton transport. The results of the fuel cell performance are shown in Fig. 4.

As seen in Fig. 4, the fuel cell performance reaches that of the best commercial sample (Celtec $®$ P1000). Three regions can be observed on the polarization curves for 1a and the commercial sample. An activation polarization region $\left(1^{\text {st }}\right)$ is observed at low current density values (approximately $<0.15 \mathrm{~A} \mathrm{~cm}^{-2}$ in the given case) and is related to the activation energy barrier on the electrode. A slightly lower voltage for 1 a from $0-0.1 \mathrm{~A} \mathrm{~cm}^{-2}$ might be related to the slightly higher overpotential for the oxygen reduction reaction. Ohmic losses are predominantly responsible for further potential decrease at approximately $0.15-0.7 \mathrm{~mA} \mathrm{~cm}^{-2}$ in the ohmic polarization region $\left(2^{\text {nd }}\right)$. These losses are very similar for both samples and could be evaluated to be $50-70 \mathrm{~m} \Omega$. The $R$ value corresponds to that taken from the EIS measurement at $0.4 \mathrm{~A} \mathrm{~cm}^{-2}$ in the low frequency region,

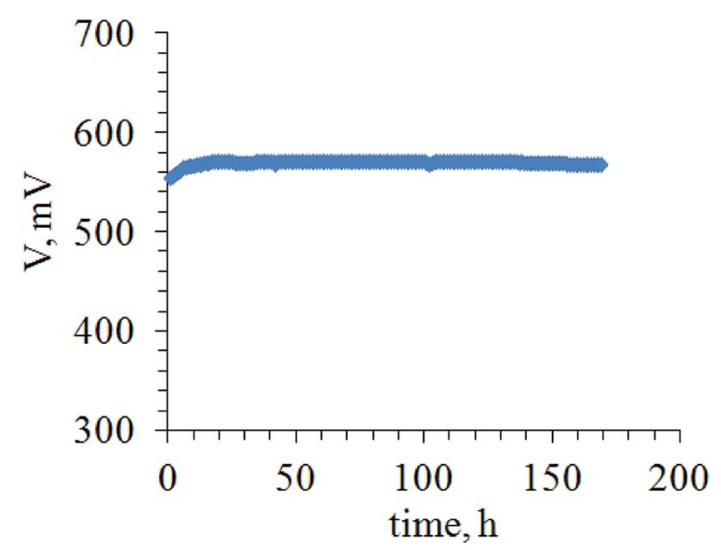

Fig. 6 Time test for $1 \mathrm{a}$ in galvanostatic mode $\left(0.6 \mathrm{~A} \mathrm{~cm}^{-2}, 180{ }^{\circ} \mathrm{C}\right)$.

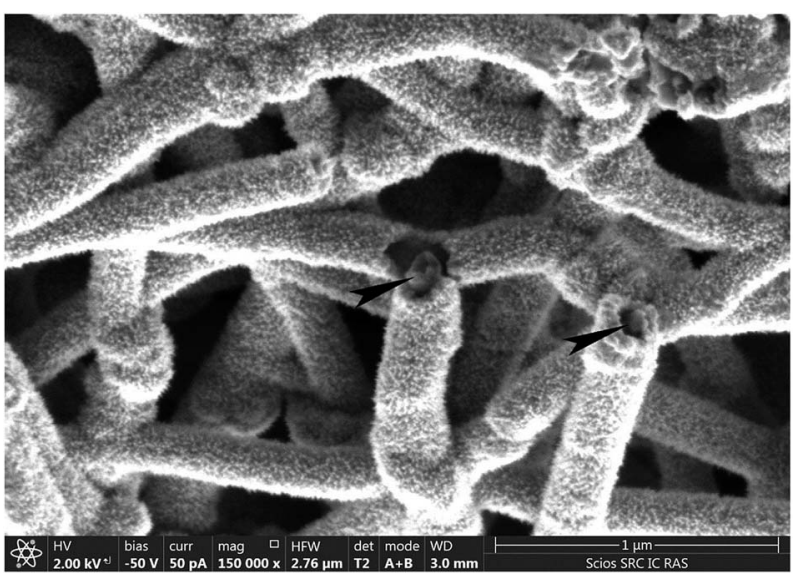

Fig. 7 SEM of nanofibers for 1a. Arrows indicate the carbon nanofiber cracks. Pt nanoparticles cover the surface of the nanofibers. 


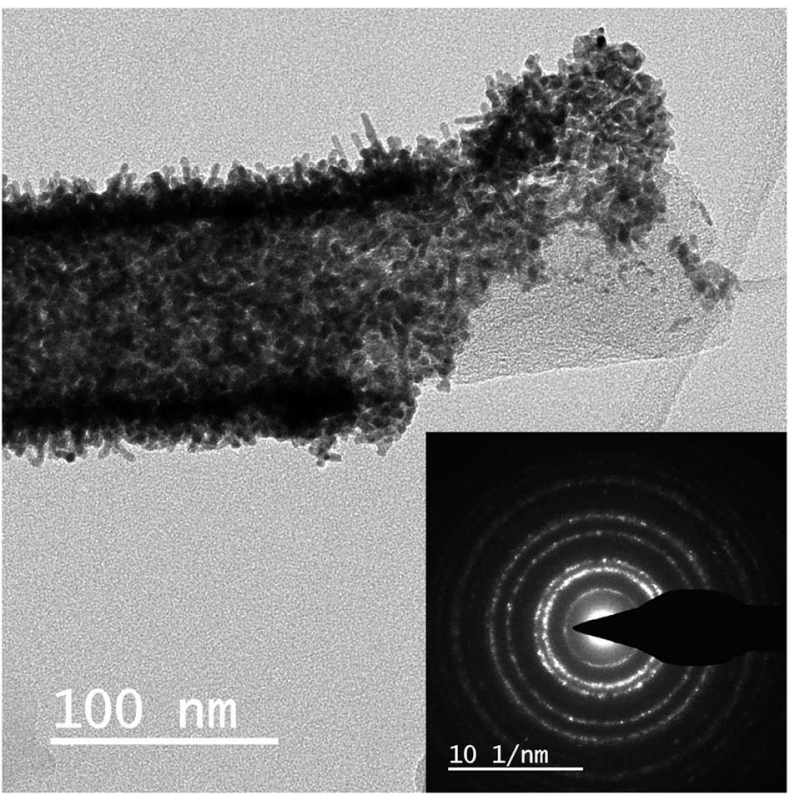

Fig. 8 The structure of Pt/PAN/Vulcan/Zr/Ni-350-1000 (sample 1a): TEM image of a single fiber fragment and corresponding diffraction pattern of a single fiber, interplanar distances reveal Pt and graphite (inset).

which is found to be $\sim 65 \mathrm{~m} \Omega$. A concentration polarization region $\left(3^{\mathrm{rd}}\right)$ is observed at current densities $>0.7 \mathrm{~A} \mathrm{~cm}^{-2}$, where losses related to gas transfer limitations predominantly on the cathode take place, especially in the case where air is used instead of oxygen. It can be noticed that mass-transfer losses are lower for 1a, which points to the better performance of the nanofiber based cathode at $>0.7 \mathrm{~A} \mathrm{~cm}^{-2}$, probably, due to its better gas-diffusion properties. At the same time, the exact quantification of the losses corresponding to these regions on the polarization curves might be complicated because of the multiple overlapping processes involved.

It is interesting to mention that the variation of $\mathrm{Zr}$ and $\mathrm{Ni}$ content, such as the increase of $\mathrm{Zr}$ and decrease of Ni content in the cathode composition (samples $2 \mathrm{a}$ and $3 \mathrm{a}$ ) of Pt/PAN/Vulcan/ $\mathrm{Zr} / \mathrm{Ni}-350-1000$ leads to a lower fuel cell performance (Fig. 5).

We suppose that the increase of Ni content up to $6 \%$, incorporated into the electrocatalyst support (1, Table 1$)$, is responsible for the better fuel cell performance. This is due to the decrease in the overpotential of the oxygen reduction reaction at high temperature in the phosphoric acid media. However, the complete explanation for the increase in the fuel cell performance is not clear so far and needs further investigation. At the same time, the low Ni content for samples 2 and 3 leads to a lower fuel cell performance. In spite of the difference in the $\mathrm{Zr}$ content ( $2.3 \%$ for 2 and $1.1 \%$ for 3 , Table 1 ), the fuel cell performances do not differ much except for the activation loss regions shown on the polarization curves; where the fuel cell performance is slightly lower for 2 and can be explained by the fact that the excess of $\mathrm{Zr}$ triggers the lower electrode performance. Also, as can be seen from the experimental results, the increasing $\mathrm{Zr}$ content does not improve the cell performance and it means that the $\mathrm{Zr}$ content should not exceed $1 \%$.

In terms of durability, a time-test at $0.6 \mathrm{~A} \mathrm{~cm}^{-2}$ conducted in galvanostatic mode shows quite stable value of about $570 \mathrm{mV}$ during $170 \mathrm{~h}$ of fuel cell operation at $180{ }^{\circ} \mathrm{C}$ (Fig. 6). The fuel cell power was found to be up to $342 \mathrm{~mW} \mathrm{~cm}^{-2}$.

\section{Electron microscopy}

The method of electrospinning from a polymer solution followed by pyrolysis allows the achievement of a perfect
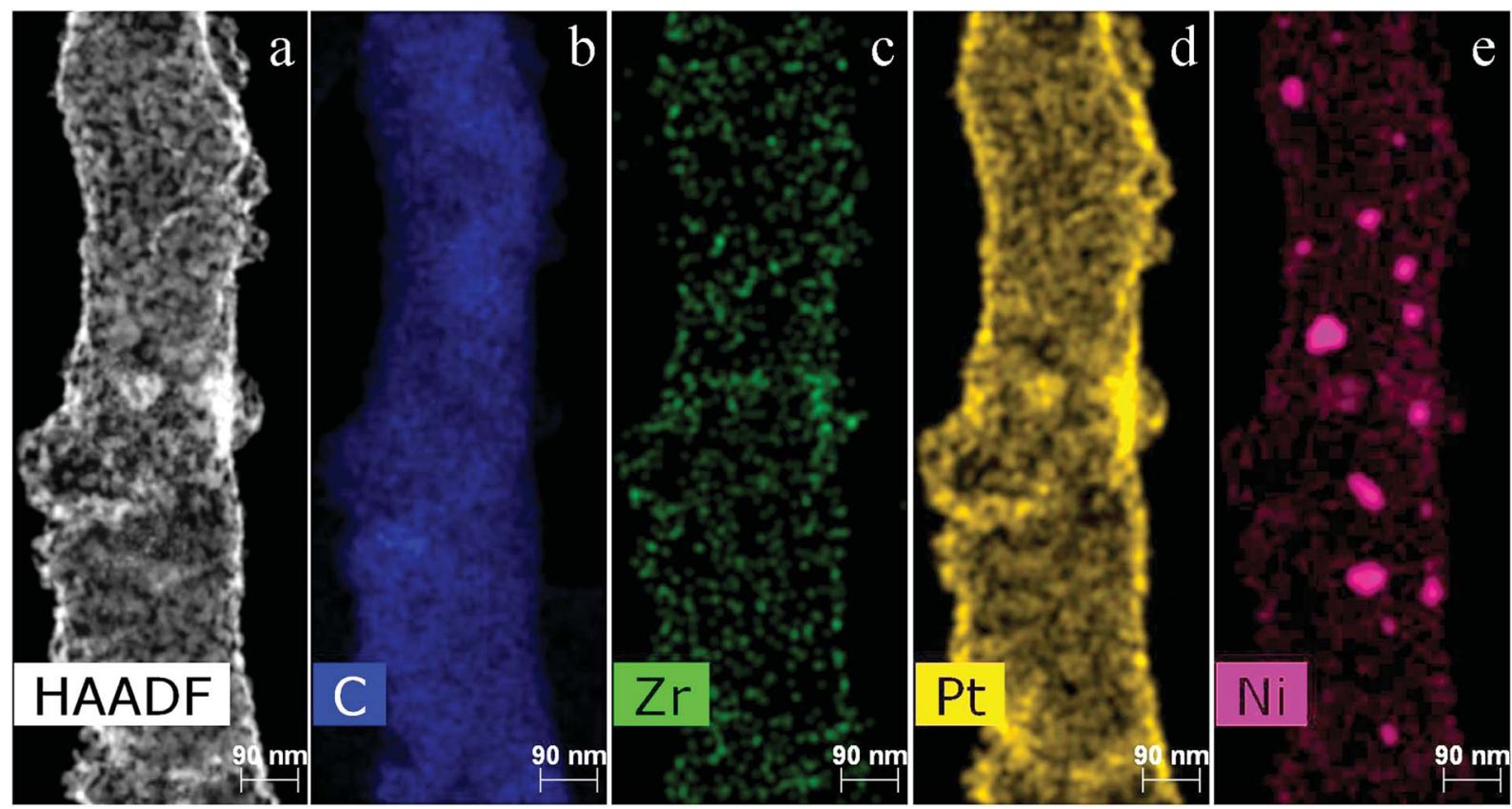

Fig. 9 High angle annular dark field scanning transmission electron microscopy (HAADF STEM) image of a part of the Pt covered fiber (a) and corresponding EDX maps of C (b), $\mathrm{Zr}$ (c), Pt (d) and $\mathrm{Ni}(\mathrm{e})$ taken from the area shown (a). 

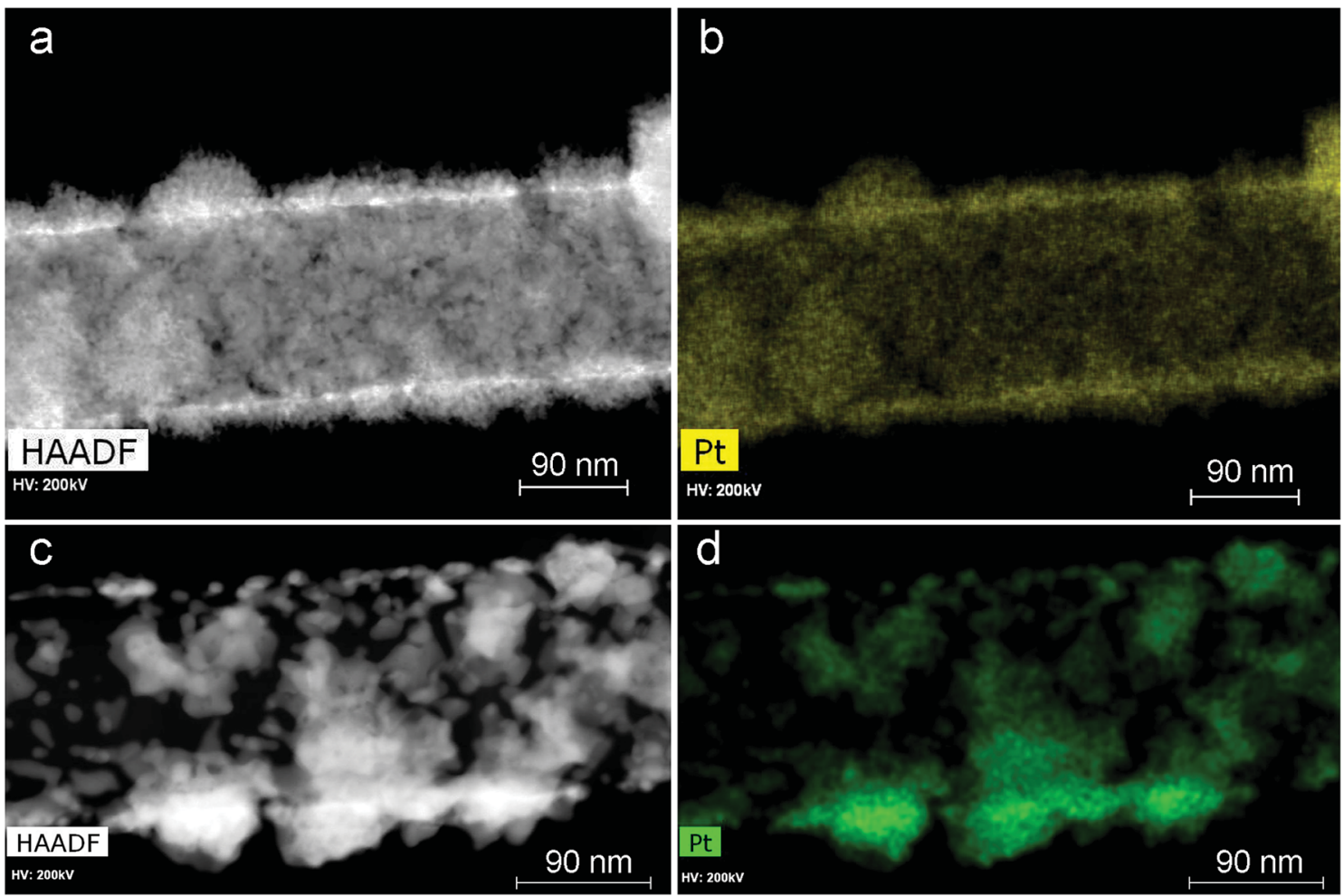

Fig. 10 HAADF STEM images and corresponding elemental maps before ( $a$ and $b$ ) and after 7 days of fuel cell testing (c and d).

distribution of nickel and zirconium throughout the carbon nanofibers. Using TEM, SEM, electron diffraction and energydispersive X-ray spectroscopy (EDX), it was shown that in 1a, the platinum nanocrystals have a uniform distribution on the nanofiber surface (Fig. 7).

Zirconium and nickel are homogeneously distributed throughout the nanofiber volume. As for $\mathrm{Ni}$, we observe its homogeneous distribution in combination with nanoparticles, with a size of several tens of nanometers, on the CNFs (Fig. 8).

Fig. 9 provides additional information about the $\mathrm{Pt}$ morphology on the nanofibers and additionally confirms its uniform distribution.

As seen in Fig. 9, the $\mathrm{Ni}$ and Pt distribution is similar. However, $\mathrm{Ni}$ also forms large nanoparticles in addition to the smaller ones. It, most probably, confirms that Pt deposits on $\mathrm{Ni}$ seeds during the process of $\mathrm{Pt}$ deposition from the aqueous solution in the presence of formic acid. The $\mathrm{Zr}$ distribution is slightly different; it corresponds to separate $\mathrm{Zr}$ particles that are probably in the form of $\mathrm{ZrO}_{x}$.

To investigate the Pt morphology, HAADF STEM images and corresponding elemental $(\mathrm{Pt})$ maps were obtained for sample 1a, before and after 7 days of fuel cell testing (Fig. 10).

It was found that coarsening of the platinum particles does not lead to immediate degradation of the fuel cell performance. The time test (Fig. 6) shows that the fuel cell can operate over long periods of time without a significant performance loss.

\section{Raman spectroscopy}

Raman spectra for samples 1 and 1a are shown in Fig. 11.
The D and G bands are clearly seen in the Raman spectra. These bands are related to partially graphitized $\mathrm{sp}^{2}$-carbon materials. In our case, it also suggests incomplete graphitization of the carbon material after pyrolysis at $1000{ }^{\circ} \mathrm{C}$.

\section{XRD analysis}

$\mathrm{XRD}$ of the electrocatalyst support (sample 1) is shown in Fig. 12.

In Fig. 8, the graphite and nickel related lines are clearly seen. Particularly, a peak at $26^{\circ}$ corresponds to the 002 graphite line. Peaks at $45^{\circ}, 52^{\circ}, 76^{\circ}$ correspond to the $111,200,220$

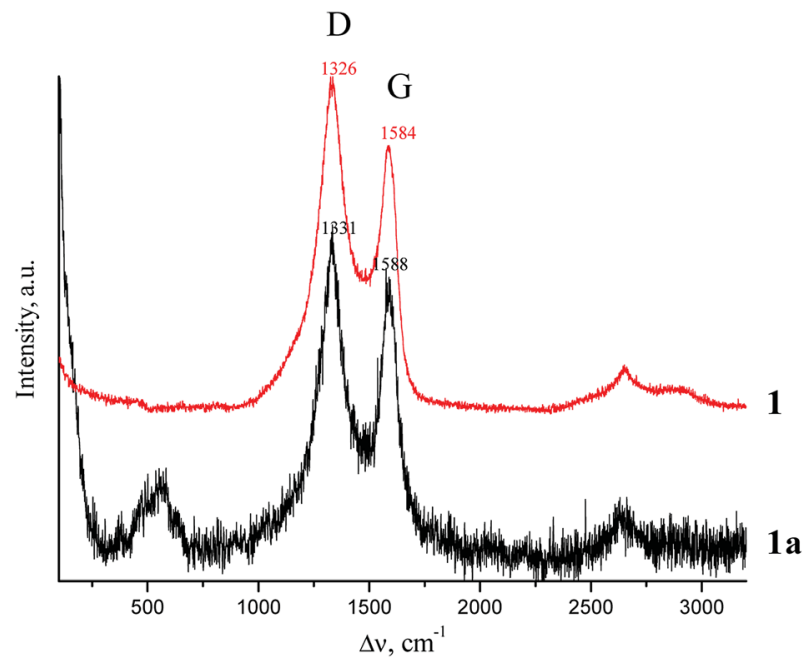

Fig. 11 Raman spectra for sample 1 and platinized sample 1a. 


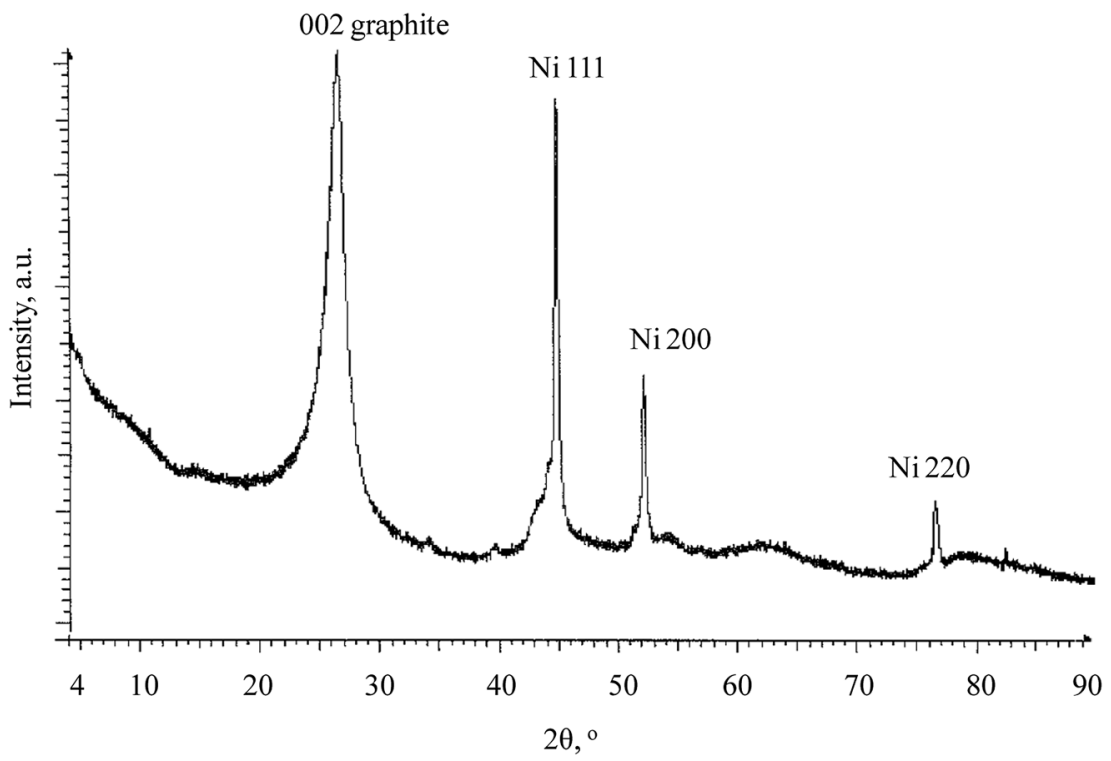

Fig. 12 XRD of the electrocatalyst support (sample 1).

nickel(0) lines. This clearly confirms the partially graphitized structure of the sample and also $\mathrm{Ni}(0)$ presence in the sample.

\section{XPS studies}

Due to the heterogeneity of the CNFP electrode morphology and the demonstrated fuel cell performance dependence on the elemental content, X-ray photoelectron spectroscopy (XPS) studies were performed in order to obtain more information concerning the surface of the composite electrode.

No contamination peaks were recorded in the survey spectra of the examined samples. According to the XPS quantitative analysis, the compositions of samples 1 and $1 \mathrm{a}$ are $\mathrm{C}_{91.55} \mathrm{~N}_{4.55^{-}}$ $\mathrm{O}_{3.59} \mathrm{Ni}_{0.11} \mathrm{Zr}_{0.21}$ and $\mathrm{C}_{65.92} \mathrm{~N}_{2.54} \mathrm{O}_{9.40} \mathrm{Pt}_{21.60} \mathrm{Ni}_{0.29} \mathrm{Zr}_{0.25}$ (on the surface), respectively. The high-resolution $\mathrm{C} 1 \mathrm{~s}$ spectra (Fig. 12 and 13) were fitted using the procedure described elsewhere. ${ }^{29}$

The C 1s spectra of samples 1 and 1a were fitted with six and four states. Their characteristics are presented in Table 2 .

Fig. 13 and Table 2 clearly demonstrate that the chemical states of the carbon atoms change after platinum deposition. Two carbon groups, namely $\mathrm{C}-\mathrm{Ni}$ and $\mathrm{C}-\mathrm{C} / \mathrm{CH}$, are not observed in the $\mathrm{C} 1 \mathrm{~s}$ spectrum of sample $1 \mathrm{a}$, the relative intensity of the $\mathrm{sp}^{2}$ state $(\mathrm{C}=\mathrm{C})$ is about twice as that in sample 1 .

Fig. 14 shows the Pt $4 \mathrm{f}$ spectrum of sample 1a. The binding energy of the $\mathrm{Pt} 4 \mathrm{f}_{7 / 2}$ peak referenced to the graphitic C $1 \mathrm{~s}$ core level at $284.44 \mathrm{eV}$ is $71.44 \mathrm{eV}$. Both the binding energy and the $\mathrm{Pt}$ $4 f_{5 / 2}-4 f_{7 / 2}$ spin-orbit splitting of $3.30 \mathrm{eV}$ indicate that $\mathrm{Pt}$ is in a zero oxidation state. The energy shift of $0.31 \mathrm{eV}$ relative to the spectrum of the Pt foil ${ }^{26}$ may be assigned to the size effect in the photoelectron spectra. ${ }^{30}$ According to TEM data, the size of $\mathrm{Pt}$ nanoparticles is about $2 \mathrm{~nm}$.

Fig. 15 shows the Ni $2 \mathrm{p}_{3 / 2}$ spectra of samples 1 and $1 \mathrm{a}$.

The main peaks at 854.78 and $855.67 \mathrm{eV}$ indicate that the $\mathrm{Ni}$ atoms are predominantly in the oxide state. ${ }^{31}$ The intense satellites at around $862 \mathrm{eV}$ characterize the oxide state as well.
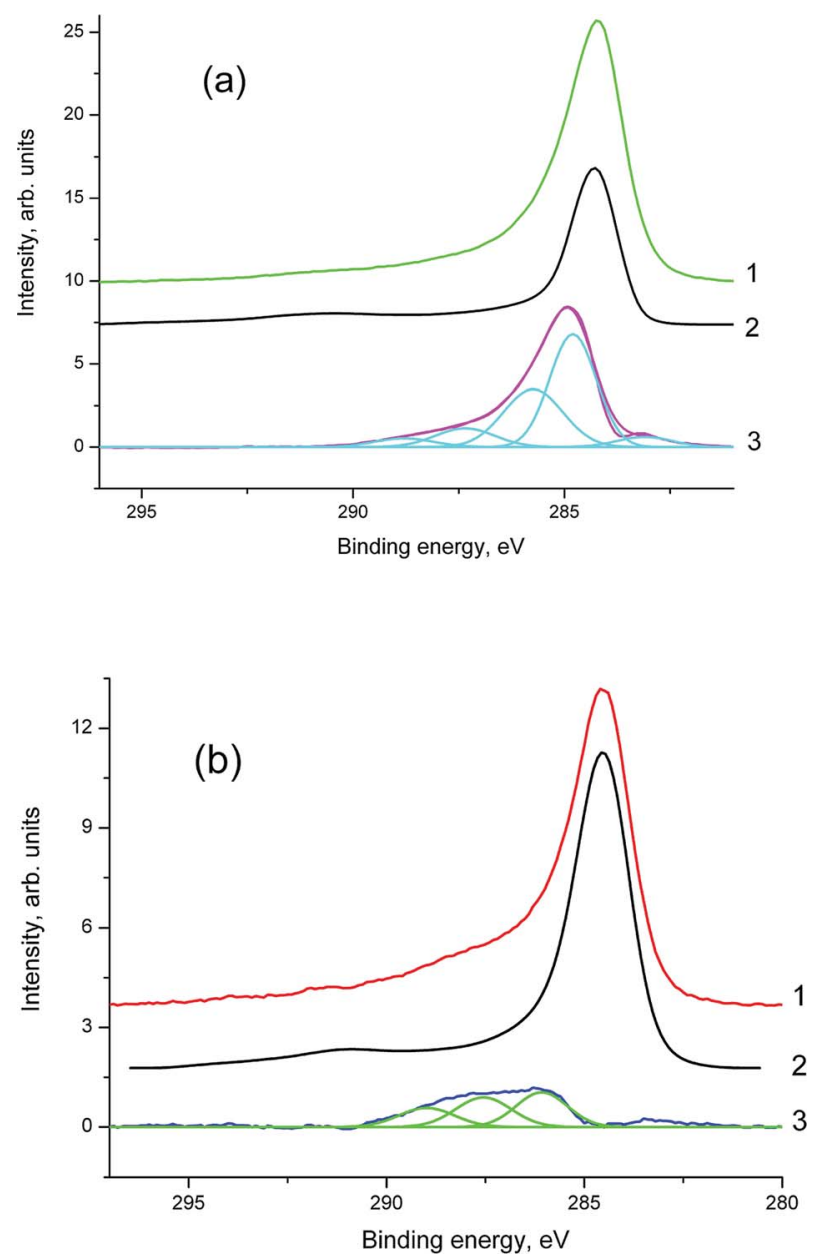

Fig. 13 High resolution XPS C 1 s spectra of samples $1(a, 1)$ and $1 a(b, 1)$, HOPG (2) and the difference spectra fitted with Gaussian profiles (3). The spectra are normalized by the $\pi-\pi^{*}$ satellite intensity. 
Table 2 Binding energies (BE) and relative intensities $\left(I_{\text {rel }}\right)$ of some groups for the $C 1$ s spectra of samples 1 and 1 a

\begin{tabular}{llcrcrrr}
\hline Sample & & $\mathrm{C}-\mathrm{Ni}$ & $\mathrm{C}=\mathrm{C}$ & $\mathrm{C}-\mathrm{C} / \mathrm{CH}$ & $\mathrm{C}-\mathrm{O}$ & $\mathrm{O}-\mathrm{C}-\mathrm{O}$ & $\mathrm{C}(\mathrm{O}) \mathrm{O}$ \\
\hline & BE, eV & 283.3 & 284.44 & 285.0 & 286.0 & 287.55 & 289.0 \\
1 & $I_{\text {rel }, \text { a.u. }}$ & 0.03 & 0.49 & 0.25 & 0.16 & 0.05 & 0.02 \\
$1 \mathrm{a}$ & $I_{\text {rel }, \text { a.u. }}-$ & 0.84 & - & 0.06 & 0.06 & 0.04
\end{tabular}

Asymmetry observed in the Ni $2 \mathrm{p}_{3 / 2}$ peak of sample $1 \mathrm{a}$ may be an indicator of two different chemical states. Taking into account the size effect, one can propose that some $\mathrm{Ni}$ atoms may be in the $\mathrm{Ni}^{0}$ state. Moreover, the energy difference between the main peak and the satellite in spectrum $1(\Delta E=6.38 \mathrm{eV})$ does not correspond to those in $\mathrm{NiO}, \mathrm{Ni}_{2} \mathrm{O}_{3} \cdot 6 \mathrm{H}_{2} \mathrm{O}, \mathrm{Ni}(\mathrm{OH})_{2}, \alpha-$ $\mathrm{Ni}(\mathrm{OH})_{2}, \beta-\mathrm{Ni}(\mathrm{OH})_{2}$ and $\gamma-\mathrm{NiOOH}_{2}$, which are in the range of 5.6-6.1 eV. ${ }^{31-36}$ A comparison of these $\Delta E$ values reveals a twocomponent structure in the $\mathrm{Ni} 2 \mathrm{p}_{3 / 2}$ spectrum 1 as in spectrum 2.

The Zr 3d spectra presented in Fig. 16 and 17 correspond to the $\mathrm{ZrO}_{2}$ state. ${ }^{28}$

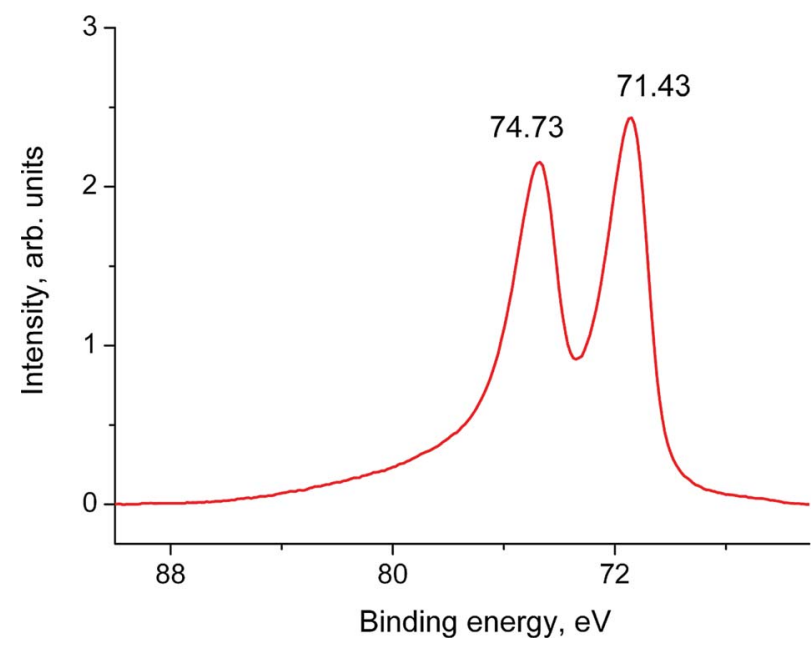

Fig. 14 The Pt 4 f spectrum of sample 1a.

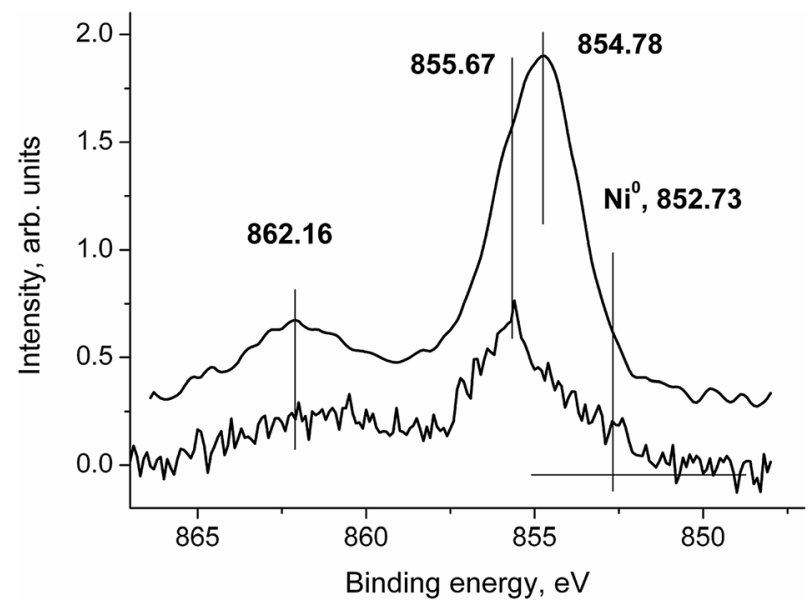

Fig. 15 The Ni $2 p_{3 / 2}$ spectra of samples 1 (top) and 1 a (bottom).

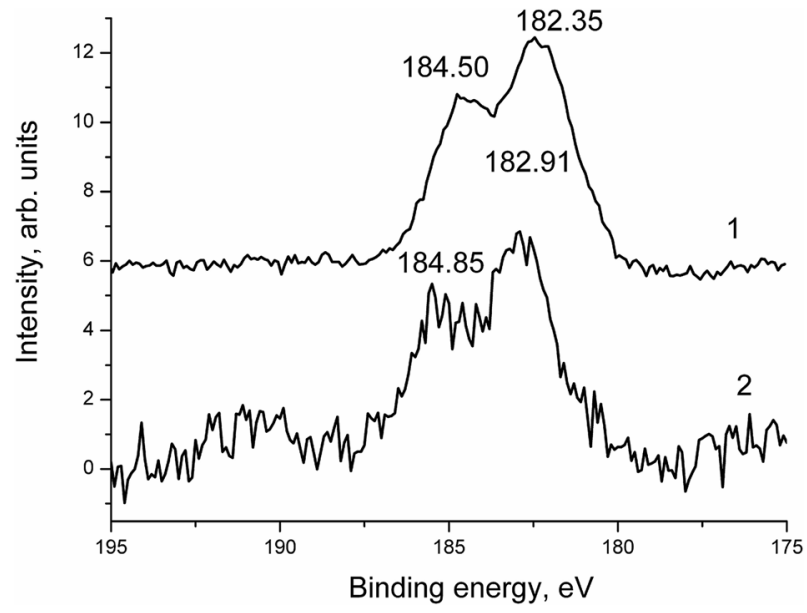

Fig. 16 The $\operatorname{Zr} 3 d$ spectra of samples 1 (1) and $1 a$ (2).

The difference in binding energies may be assigned to either the size effect or the different surroundings. Fig. 18 shows high resolution XPS N 1s spectra of samples 1 (1) and 1a (2) fitted with some components.

The $\mathrm{N} 1 \mathrm{~s}$ spectra of samples 1 and $1 \mathrm{a}$ were fitted with three components related to the nitrogen-metal $(\mathrm{N}-\mathrm{Me})$ bond $(1,2)$, $\mathrm{N}-\mathrm{C}(\mathrm{O})$ group $(1,2), \mathrm{N}-\mathrm{O}_{x}(1)$ and $\mathrm{NH}^{3+}$ groups. ${ }^{37}$ XPS studies confirm the presence of $\mathrm{ZrO}_{x}, \mathrm{Ni}(0), \mathrm{N}$ and $\mathrm{Pt}$ on the surface of
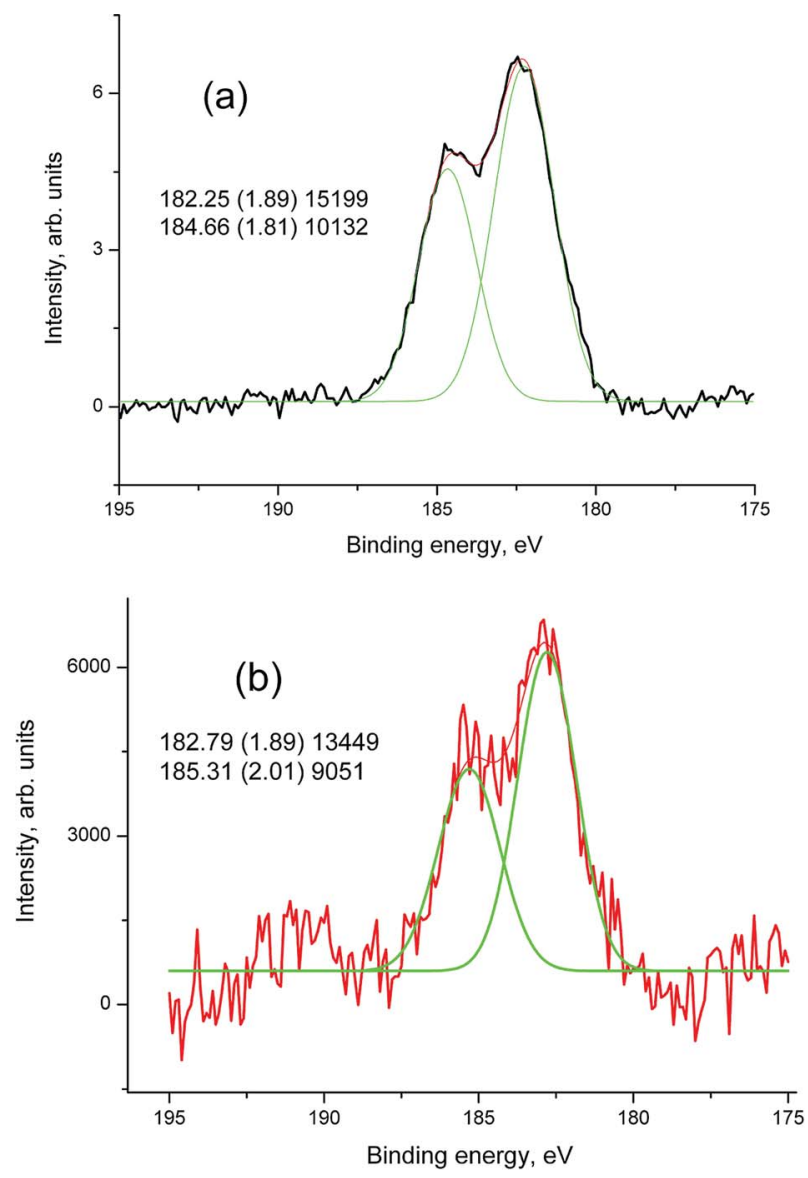

Fig. 17 The fitted Zr 3d spectra of samples 1 (a) and 1a (b). 

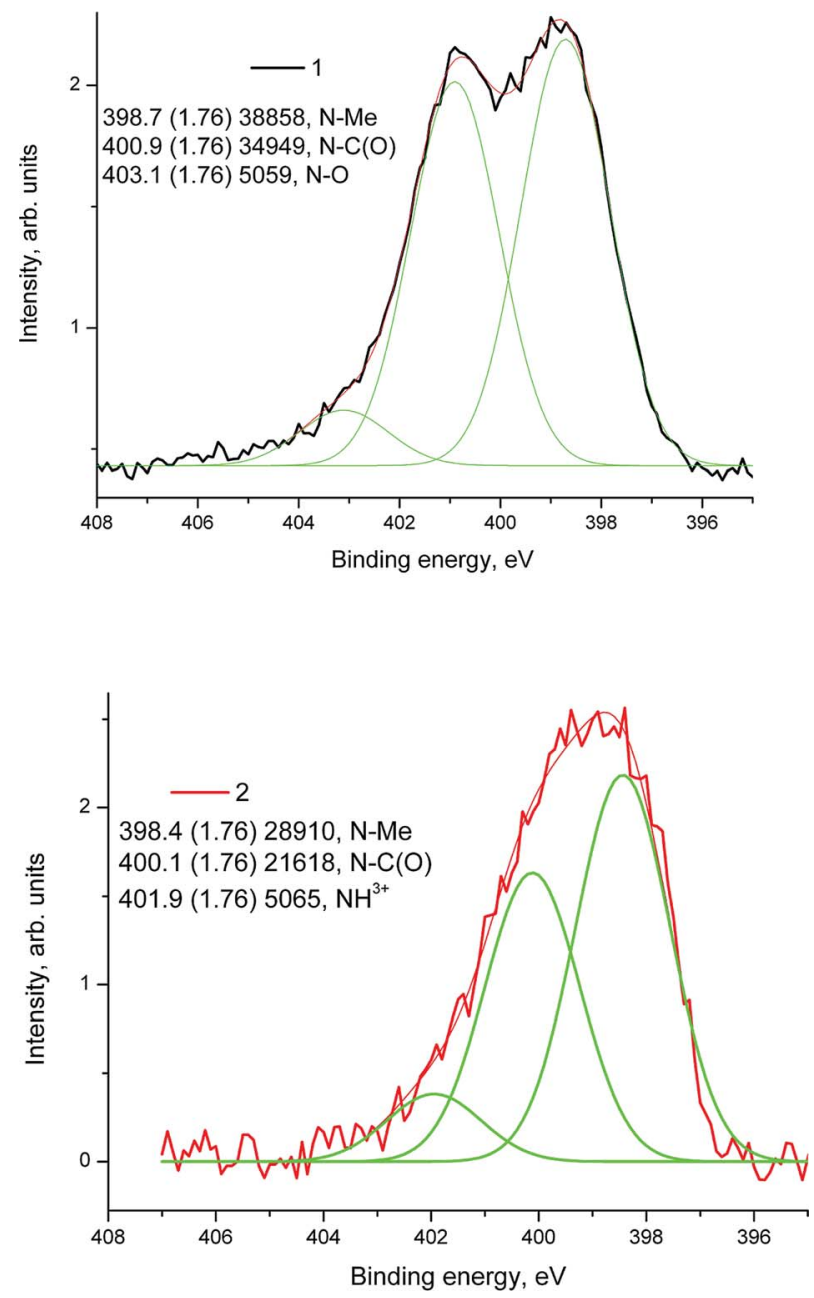

Fig. 18 High resolution XPS N 1s spectra of samples 1 (1) and 1a (2) fitted with some components.

the composite HT-PEMFC electrode and provide important information about their chemical states.

\section{Conclusions}

A new concept for carbon nanofiber paper-based fuel cell gasdiffusion electrode design was proposed and demonstrated to be useful for HT-PEMFC on a polybenzimidazole membrane. The electrodes are produced by the electrospinning method from a polymer solution with further pyrolysis, in order to finally obtain a more durable nanofiber electrode compared with carbon black ones. Introduction of $\mathrm{ZrO}_{x}$ and $\mathrm{Ni}(0)$ into the carbon nanofiber paper platinum support during the electrospinning step leads to a higher fuel cell performance comparable to Celtec ${ }^{\circledR} \mathrm{P} 1000$, one of the best commercial electrodes.

\section{Conflicts of interest}

There are no conflicts of interest to declare.

\section{Acknowledgements}

The authors would like to thank V. V. Emets, S. S. Bukalov and M. Kondratenko for their help. The study was financially supported by Russian Science Foundation, grant \# 18-13-00421.

\section{References}

1 J. Zhang, PEM Fuel Cell Electrocatalysts and Catalyst Layers, Fundamentals and Applications, Springer-Verlag, London, 2008.

2 R. E. Rosli, A. B. Sulong, W. R. W. Daud, M. A. Zulkifley, T. Husaini, M. I. Rosli, E. H. Majlan and M. A. Haque, Int. J. Hydrogen Energy, 2017, 42, 9293-9314.

3 R. K. A. Rasheed, Q. Liao, Z. Caizhi and S. H. Chan, Int. J. Hydrogen Energy, 2017, 42, 3142-3165.

4 Q. Li, D. Aili, H. A. Hjuler and J. O. Jensen, High Temperature Polymer Electrolyte Membrane Fuel Cells, Approaches, Status and Perspectives, Springer, Cham, Heidelberg, New York, Dordrecht, London, 2016.

5 R. Zeis, Beilstein J. Nanotechnol., 2015, 6, 68-83.

6 S. S. Araya, F. Zhou, V. Liso, S. L. Sahlin, J. R. Vang, S. Thomas, X. Gao, C. Jeppesen and S. K. Kaer, Int. J. Hydrogen Energy, 2016, 41, 21310-21344.

7 A. Chandan, M. Hattenberger, A. El-kharouf, S. Du, A. Dhir, V. Self, B. G. Pollet, A. Ingram and W. Bujalski, J. Power Sources, 2013, 231, 264-278.

8 X. X. Wang, Z. H. Tan, M. Zeng and J. N. Wang, Sci. Rep., 2014, 4, 4437.

9 J. Lobato, H. Zamora, J. Plaza, P. Canizares and M. A. Rodrigo, Appl. Catal., B, 2016, 198, 516-524.

10 H. Zamora, J. Plaza, P. Canizares, J. Lobato and M. A. Rodrigo, ChemSusChem, 2016, 9, 1187-1193.

11 Z. Xia, S. Wang, L. Jiang, H. Sun, S. Liu, X. Fu, B. Zhang, D. S. Su, J. Wang and G. Sun, Sci. Rep., 2015, 5, 16100.

12 K. M. Skupov, I. I. Ponomarev, D. Y. Razorenov, V. G. Zhigalina, O. M. Zhigalina, I. I. Ponomarev, Y. A. Volkova, Y. M. Volfkovich and V. E. Sosenkin, Russ. J. Electrochem., 2017, 53, 728-733.

13 I. I. Ponomarev, I. I. Ponomarev, I. Y. Filatov, Y. N. Filatov, D. Y. Razorenov, Y. A. Volkova, O. M. Zhigalina, V. G. Zhigalina, V. V. Grebenev and N. A. Kiselev, Dokl. Phys. Chem., 2013, 448, 23-27.

14 I. I. Ponomarev, K. M. Skupov, D. Y. Razorenov, V. G. Zhigalina, O. M. Zhigalina, I. I. Ponomarev, Y. A. Volkova, M. S. Kondratenko, S. S. Bukalov and E. S. Davydova, Russ. J. Electrochem., 2016, 52, 735-739.

15 M. S. Kondratenko, I. I. Ponomarev, M. O. Gallyamov, D. Y. Razorenov, Y. A. Volkova, E. P. Kharitonova and A. R. Khokhlov, Beilstein J. Nanotechnol., 2013, 4, 481-492.

16 A. I. Fomenkov, I. V. Blagodatskikh, I. I. Ponomarev, Y. A. Volkova, I. I. Ponomarev and A. R. Khokhlov, Polym. Sci., Ser. B, 2009, 51, 166-173.

17 I. I. Ponomarev, D. Y. Razorenov, I. I. Ponomarev, Y. A. Volkova and K. M. Skupov, Russ. J. Electrochem., 2014, 50, 694-699. 
18 Z. Dong, S. J. Kennedy and Y. Wu, J. Power Sources, 2011, 196, 4886-4904.

19 M. Ignaki, Y. Yang and F. Kang, Adv. Mater., 2012, 24, 25472566.

20 B. Zhang, F. Kang, J.-M. Tarascon and J.-K. Kim, Prog. Mater. Sci., 2016, 76, 319-380.

21 T. K. Tenchurin, A. N. Krasheninnikov, A. S. Orekhov, S. N. Chvalun, A. D. Shepelev, S. I. Belousov and A. I. Gulyaev, Fibre Chem., 2014, 46, 151-160.

22 M. V. Rylkova, E. S. Bokova, G. M. Kovalenko and I. Y. Filatov, Fibre Chem., 2012, 44, 146-148.

23 L. Ji, Z. Lin, A. J. Medford and X. Zhang, Carbon, 2009, 47, 3346-3354.

24 N. Yusof and A. F. Ismail, J. Anal. Appl. Pyrolysis, 2012, 93, 113.

25 V. G. Zhigalina, O. M. Zhigalina, I. I. Ponomarev, K. M. Skupov, D. Y. Razorenov, I. I. Ponomarev, N. A. Kiselev and G. Leitinger, CrystEngComm, 2017, 19, 3792-3800.

26 T. J. Schmidt and J. Baurmeister, J. Power Sources, 2008, 176, 428-434.

27 T. Chen, Y. Tang, Y. Qiao, Z. Liu, W. Guo, J. Song, S. Mu, S. Yu, Y. Zhao and F. Gao, Sci. Rep., 2016, 6, 23289.
28 A. V. Naumkin, A. Kraut-Vass, S. W. Gaarenstroom and C. J. Powell, NIST X-ray Photoelectron Spectroscopy Database, Version 4.1, National Institute of Standards and Technology, Gaithersburg, 2012, https://srdata.nist.gov/xps/ , accessed June 2018.

29 N. S. Komarova, A. G. Krivenko, A. G. Ryabenko and A. V. Naumkin, Carbon, 2013, 53, 188-196.

30 W. Eberhardt, P. Fayet, D. M. Cox, Z. Fu, A. Kaldor, R. Sherwood and D. Sondericker, Phys. Rev. Lett., 1990, 64, 780-783.

31 A. N. Mansour, Surf. Sci. Spectra, 1994, 3, 231-238.

32 A. N. Mansour and C. A. Melendres, Surf. Sci. Spectra, 1994, 3, 263-270.

33 A. N. Mansour and C. A. Melendres, Surf. Sci. Spectra, 1994, 3, 247-254.

34 A. N. Mansour and C. A. Melendres, Surf. Sci. Spectra, 1994, 3, 255-262.

35 A. N. Mansour, Surf. Sci. Spectra, 1994, 3, 239-246.

36 A. N. Mansour and C. A. Melendres, Surf. Sci. Spectra, 1994, 3, 271-278.

37 G. Beamson and D. Briggs, High Resolution XPS of Organic Polymers. The Scientia ESCA300 Database, Wiley, Chichester, 1992. 